\title{
Retrospection of Knowledge, Attitude and Practices on the Sustainability in Contemporary Scientific Literature 2015 to 2020
}

\author{
BALAMOUROUGANE. ${ }^{1}$, SRUTHI KANNAN ${ }^{2}$ \\ ${ }^{1}$ LEAD COLLEGE OF MANAGEMENT, PALAKKAD, KERALA \\ ${ }^{1}$ E-mail:bala@lead.ac.in \\ ${ }^{2}$ E-mail: sruthikannan@lead.ac.in
}

\begin{abstract}
As the nations united for urgent solutions during urgent times as per the direction of United Nation on Sustainability Development Goals (SDGs), the present study attempts to explore the existing literature reviews on KAP towards sustainability in various sectors. People wish to adapt to the sustainability in order to chime in with the nature and its systems as it will contribute positively to them. Research papers related to this study are gathered from the potential sources, organised and sequenced to understand the most, moderate and least addressed sector. Within the review the researcher provides a snapshot of the methodology and findings of each study. The sectors to be focused more in the future studies are agriculture, construction and banking.
\end{abstract}

Keywords: KAP; Sustainability; SDGs.

JEL Classification: C1, L2

Received: June 02, 2021

Accepted: September 30, 2021 


\title{
Retrospección de Conocimientos, Actitudes y Prácticas sobre la Sostenibilidad en la Literatura Científica Contemporánea de 2015 a 2020
}

\author{
BALAMOUROUGANE. ${ }^{1}$, SRUTHI KANNAN ${ }^{2}$ \\ ${ }^{1}$ LEAD COLLEGE OF MANAGEMENT, PALAKKAD, KERALA \\ ${ }^{1}$ E-mail:bala@lead.ac.in \\ ${ }^{2}$ E-mail: sruthikannan@lead.ac.in
}

\begin{abstract}
RESUMEN
Dado que las naciones se han unido para buscar soluciones urgentes en tiempos de urgencia según la dirección de las Naciones Unidas sobre los Objetivos de Desarrollo Sostenible (ODS), el presente estudio trata de explorar las revisiones de la literatura existente sobre el CAP hacia la sostenibilidad en varios sectores. Las personas desean adaptarse a la sostenibilidad para estar en sintonía con la naturaleza y sus sistemas, ya que esto contribuirá positivamente a su bienestar. Los trabajos de investigación relacionados con este estudio se recogen de las posibles fuentes, se organizan y se secuencian para comprender el sector más, el más moderado y el menos abordado. Dentro de la revisión, el investigador ofrece un resumen de la metodología y las conclusiones de cada estudio. Los sectores en los que se centrará más en los futuros estudios son la agricultura, la construcción y la banca.
\end{abstract}

Palabras clave: CAP; Sostenibilidad; ODS.

Clasificación JEL: C1, L2 


\section{Introduction}

Through KAP study, it measures the extent of a known situation and enhances the knowledge, attitude and practices around specific themes. In the present context the present paper is ascertain to study on understanding the knowledge, attitudes and practices towards sustainability on certain sectors. This study tries to identify the sectors in which KAP study on sustainability are most addressed, moderately addressed and least addressed. Hence, this study focused on exploring sustainability knowledge. The use of knowledge, attitudes and practices (KAP) methodology began within the mid-20th century when KAP studies began to investigate the vast negative attitude towards planning services. The aim of KAP studies is to form situation analyses which help to grasp which actions should be taken and what quite interventions should be applied. KAP surveys are now a widely used methodology for studying human behaviour when littered with an issue. It is also learnt during the study that there exist a very limited number of studies related to evaluation of the KAP model and also the lack of systematic review on the same (Salas - Zapta, Rios-Osorio, \& CardonaArias, 2018).

\section{Objectives of the study:}

i. To find out the scope of the KAP study on sustainability in the research area ii. To explore the sectors which are most and least addressed by the KAP study iii. To provide a snapshot of the sector, methodology and outcome adopted in earlier studies on KAP

\section{Results and Discussions}

Results are taken from the recent research papers which have conducted their study on the KAP on sustainability. After doing a prima facie observation the studies which are not falling into the ambit of the scope of this study are neglected and the relevant ones are taken for further analysis. The table constructed at the end of this study will show the purpose of each study, the population used for collecting samples, methods of sampling, statistical test used, and the outcomes of each study. List of the important research paper with the current area of interest are discussed below:

1. Muhammad Uzair Ali et.al (2020) conducted a study to recognize KAP of Islamic banking and conventional banking clients in Federal Administrated Tribal Areas \& Political Administrated Tribal Areas of Pakistan (FATA and PATA). Number of products and the available services, Presence of number branches, service speed, dependability and the outcome of the transaction are the important variables in this study. 'Chi-square' is the tool used for the analysis. The positive association between the KAP of Islamic bank and sustainability is revealed from the outcome of the study. It suggests the Islamic banks on making awareness on their products and services to sustain in the future.

2. Xiyao Liu et.al (2020) attempted to understand the KAP of functional food and wellness during the adoption of culture by the international students. A survey was carried out using open- and closed-ended questions which was conducted among 473 international students in Dublin through convenience sampling. Cross-tabulations and statistical tools like Pearson Chi-square analyses were conducted to identify the participant's perception related to the status of their wellness, and Health locus of control (HLC) among demographic profile. The study concludes that International students fall into a wrong diet during their migration and it leads to unhealthy effects. Awareness on dietary knowledge is required for the international students and the Irish society and international schools must be aware of the diet during acculturation.

3. Bao-Liang Zhonget.al (2020) examined Chinese inhabitants' COVID-19 KAP through the quick ascent time of the episode. This cross-sectional review had been directed from 27th January to 1st February, succeeding the week following the confinement of Hubei Province closure. It merits referencing on when COVID-19 information KAP scores are higher, probability of adverse perspectives along with possibly risky practices are lower on the COVID-19 pandemic was found in 
this investigation. This discovery plainly shows the significance of enriching inhabitants' COVID-19 information by means of wellbeing training, which may likewise bring about enhancements in their perspectives and practices towards COVID-19 will assist them with improving their future with the capacity to continue their living propensities with accessible arrangements.

4. Ahmed Assar et.al (2020) directed a cross-sectional investigation to recognize the KAP holes in antimicrobial stewardship among Egypt's undergrad clinical understudies. Generally speaking, most of understudies displayed reasonable/agreeable information and mentality scores towards antimicrobial opposition. Instructive projects on antimicrobial administration and the function of medical care experts in forestalling AMR ought to be presented from the get-go in clinical educational programs. Further, dynamic instructive procedures as the clinical situations which mimic the clinical arrangements and intuitive training on learning can be more productive in educating strategies.

5. LESLEY C LUBOS (2019) surveyed the information, perspectives, practices, and activity of the pioneers of the 22 towns on the River Banks of the Cagayan de Oro City, Mindanao on environmental change along with ecological mindfulness on Sustainability. Over all the overviews, there was a proposal by the respondents that there is a requirement for more mindfulness and government funded instruction exercises in the network and furthermore the nearby network ought to be engaged with figuring correspondence materials to expand information and mindfulness. The investigation infers that the pioneers' information, mentalities, practices, and activities demand mediation to enrich their attention towards realise, think, and perform in a mindful way so that secures both general wellbeing and the climate.

6. Ms VarshaRammaiya et.al (2019) conducted a KAP study to understand the perception of customers on the E-banking Services to highlight the security problems of Online Banking thereby analyse the trend of E-banking with the help of primary data for sustainable E-banking activities. The results revealed that $72 \%$ of customers are using E-banking services out of total respondents. $95.3 \%$ of customers are satisfied with the use of E-banking Services. E-banking has given the new potential to the Banking Industry. It has also given the ease of life to customers by providing sustainable online banking services and saving their time.

7. Francis Oremo et.al (2019), directed the examination to get KAP in harnessing the benefits of water among Small Irrigators in the Sub-Catchment area of Tsavo, Kenya. This investigation attempts to dissect how irrigators in the study area are occupied with water management, explicitly their awareness and esteem, and their application in harnessing water; study investigates how it can educate managing water resources. An ordinal relapse arrangement had been utilized here. This examination has featured the connection between information on IWRM and disposition and practice in water management.

8. Minghui Zhaoet.al (2019), directed this investigation to investigate especially for comprehension and recognizing the components related with KAP and data request on fog contamination in Changchun, China. The outcomes stressed the significance of improving the attention to inhabitants toward dimness contamination through state funded instruction and natural insurance crusades. Discoveries recommended that the legislature ought to designate more assets towards teaching residents of the fog contamination issue, furnishing them with suitable practices to help decrease the inconvenient impacts, and urging individuals to effectively partake in and screen dimness contamination control to accomplish ceaseless improvement of air quality.

9. SoufianeZegraoui et.al (2018) plans to investigate the KAP of the liberal specialists on their accord to the public scheme marked beneath $\mathrm{MHI}$ plot and to suggest a few upgrades. The aftereffects of this examination indicated that the perspectives of wellbeing experts towards the public arrangement marked under the medical coverage plot lean on the non-regard of the public reference levies since they opine that these duties are low and don't mirror the volume and nature of administrations they give to the safeguarded. This circumstance harms the buying intensity of policyholders since they should pay a high client charge, which speaks to the distinction between the 
public reference duty discounted by the medical coverage reserves and the levy applied by the liberal specialists.

10. Illiyyeen Fatimaet.al (2018) directed the investigation to survey the KAP on with respect to optometric administrations among general professionals rehearsing in Lahore. An illustrative crosssectional examination was directed in 95 general experts. The outcomes indicated that among the 95 respondents, their training span was 6 to 15 years and the greater part of them (67.4\%) was private professionals. Information evaluation demonstrated that they had reasonable degree of information with respect to optometric administrations decided by their reactions while their attitudes were satisfactorily certain yet they didn't use their insight in their General Practice regularly.

11. M.I.C. Azami et.al (2018) directed this examination endeavouring to evaluate and distinguish the obstructions and deterrents for contractual workers in Malaysia to rehearse green development, in view of the information on the contract based workers, their demeanour on becoming environmentally friendly and their present work on, utilizing the set up strategy for KAP. The outcomes show while the degree of information and its application on the contractual workers in Malaysia on green development is acceptable, however level of mentality is excessively low and horrible. The purpose for this troublesome demeanour is the observation that green development will cause additional time and cost to their development venture. Along these lines, moving into green development, the legislature of Malaysia require to zero in on time and cost on the usage of green development through guide, for example, budgetary motivators and ability that will make the green development manageable over the long haul.

12. Xinmiao Luo et.al (2018) means to analyse sanitation KAP among the understudies from nursing, instruction and clinical schools. This study was directed across 3454 undergrads in Chongqing, China. Understudies from the school of nursing training and medication were picked in light of the fact that, they are relied upon to assume a significant part in wellbeing instruction and advancement after their graduation. The outcomes show that they had deficient information and unseemly conduct toward sanitation. Clinical UG and the nursing UG scored lower on information and practice, yet higher on demeanour.

13. James Muleme et.al (2017) led Knowledge, mentality, and practice (KAP) study to control the usage of general wellbeing intercessions (PHIs), and they are significant apparatuses for political influence. These investigations are typically pointed toward distinguishing markers that can illuminate and improve the turn of events and execution of PHIs. The discoveries in the examination uncover textures and irregularities with the KAP straight relationship just as distinguish related elements at the family unit level in Uganda. This study proposes that a pesticide security mindfulness mission would just be powerful as leading an adjustment in conduct across family units with restricted information.

14. RabiaTabassumet.al(2017)conducted the study to measure the knowledge attitude and practices of people, particularly poor and vulnerable people on social protection schemes which will help them towards sustainability living. The results of the survey demonstrate a significant knowledge gap concerning social assistance programs in selected districts. This could be mainly due to inadequate information dissemination in rural areas. Owing to prevailing high illiteracy people are unable to read, and comprehend information about such programs.

15. Morgera, Elisa, Principal Investigator (2017) conducted the study to profile and analyse KAP on food safety amongst households in order to obtain a better understanding of current levels of awareness and practices and implement educational and awareness activities to promote best practices in food handling at the household level. The findings of this study identified major gaps in food safety KAPs. Survey findings serve as a useful starting point in defining strategies for the development of a comprehensive and effective awareness campaign to promote food-safety best practices across the entire food handling life cycle. It is recommended to use public awareness campaigns to positively influence consumers' attitudes and practices, encouraging them to exercise caution during purchase, preserve, access and also making food. 
16. M.A.K.A.K.B. ROHIN (2016) led to contemplate the degree of KAP on great assembling rehearses (GMP) across food controllers in Terengganu medical clinics. This study includes four clinics and the testing technique utilized was purposive comfort examining. The information has been gathered utilizing a strategy for a poll and been dissected by utilizing SPSS. Results show that the relationship among socio-segment information elements and factors of level KAP on GMP had huge worth.

17. Da Silva (2015) In this study the author opines that teachers play an important role in the change process of creating knowledge, attitudes, and skills among the students for creating awareness on the conservation of mangroves in the area of Guyana. Samples were collected from the teachers of two areas of Guyana using a questionnaire with Cronbach's alpha level of .918, to understand their KAP level in management as well as the conservation of Mangroves. The outcome of the study reveals that their KAP level was good and there exist a positive approach to manage, conserve, and including it in teaching. Also, the study recommends that for promoting the conservation of mangroves and to motivate the teachers to maintain sustainability.

18. HumnaMehtab et.al (2015) conducted the study to recognize the motivating factors that influence the moderating attitude and ascertains how attitude affects the relationship between the knowledge and practices. This study stresses the creation of awareness of products and services of Islamic banking because only awareness regarding anything makes customers adopt things. Moreover, Islamic banking should work hard to generate a positive attitude among people about "Islamic banking". It could be done by focusing on the aspects that normally create negative or positive attitude among customers from both Islamic and conventional banks. This is significant because a negative attitude prohibits people of high knowledge of Islamic banking principles from opening accounts with Islamic banks.

19. Kolbe KD (2015) this investigation pointed toward evaluating and building up understudies' information, mentalities and conduct with respect to squander the executives. The outcomes show that understudies from the language structure school had more significant levels of information, were bound to reuse and utilized more wellsprings of data with respect to squander the board. Squander decrease was viewed as significant by practically all students. The examination demonstrated that there are contrasts between Grammar School Pupils and Comprehensive School Pupils KAP with respect to squander the executives. Both schools required to feature the significance of waste decrease along with waste re-use contrasted with reusing. The two methodologies limit the negative ecological effects and helpless asset use related with squander.

20. Jamilah Ahmad et.al (2015), this examination researched the connection between understudies' information, demeanour and practice of the climate and compelling correspondence of ecological messages. For this reason, an information, disposition and practice (KAP) overview was directed, including 895 Students from sixteen higher education organizations in Malaysia. The outcomes uncovered that understudies as a rule, have a decent degree of natural information. The discoveries of this investigation likewise recommended that the web is viewed as understudies favoured decision of media which can be used to spread ecological data. It is significant, in any case, not to ignore the functions of more customary media, for example, TV and papers, as they can likewise be adequately used to convey ecological data.

\section{Snapshot of the sector, methodology and outcome adopted in earlier studies on KAP}

To have an overall picture of the above reviews the following table is constructed to help the future researchers for making comparisons of the mentioned studies in terms of their objective, methodologies, sectors focused and their major findings. 


\begin{tabular}{|c|c|c|c|c|}
\hline S.No. & $\begin{array}{l}\text { Author andYear, } \\
\text { Sector and Location }\end{array}$ & Objective & Methodology & Outcome \\
\hline 1 & $\begin{array}{l}\text { MuhammadUzair Ali } \\
\text { et.al (2020), } \\
\text { Banking (Islamic } \\
\text { banking and } \\
\text { Conventional bank), } \\
\text { PAKISTAN }\end{array}$ & $\begin{array}{l}\text { to recognize the } \\
\text { KAP of Islamic } \\
\text { banking and } \\
\text { conventional } \\
\text { banking customers } \\
\text { in FATA and PATA } \\
\text { client's in } \\
\text { Pakistan }\end{array}$ & $\begin{array}{l}\text { The sample size of } \\
150 \text { comprises the } \\
\text { individuals who } \\
\text { maintain their } \\
\text { account in Islamic } \\
\text { bank or traditional } \\
\text { bank of FATA and } \\
\text { PATA. Chi-square } \\
\text { and ODD ratios were } \\
\text { used. }\end{array}$ & $\begin{array}{l}\text { Islamic banking } \\
\text { should work hard to } \\
\text { generate attitude } \\
\text { about the Islamic } \\
\text { banking. } \\
\text { Some of the Islamic } \\
\text { banking products or } \\
\text { services are } \\
\text { adopted by the } \\
\text { clients when they } \\
\text { have positive } \\
\text { attitude and some } \\
\text { are not. }\end{array}$ \\
\hline 2 & $\begin{array}{l}\text { Xiyao Liu et.al } \\
(2020), \\
\text { Education } \\
\text { (International } \\
\text { Students), } \\
\text { DUBLIN }\end{array}$ & $\begin{array}{l}\text { This investigation } \\
\text { intended to assess } \\
\text { the KAP of } \\
\text { functional food, } \\
\text { diet and wellbeing } \\
\text { during the } \\
\text { assimilation of } \\
\text { International } \\
\text { students in Dublin }\end{array}$ & $\begin{array}{l}\text { Convenience } \\
\text { sampling was used } \\
\text { to select } 473 \\
\text { international } \\
\text { students from } 10 \\
\text { schools through their } \\
\text { teachers in Dublin. } \\
\text { Questionnaire was } \\
\text { administered. Cross } \\
\text { Tabulation and } \\
\text { Pearson Chi-Square } \\
\text { analysis was used }\end{array}$ & $\begin{array}{l}\text { International } \\
\text { schools and Irish } \\
\text { society must create } \\
\text { awareness to } \\
\text { International } \\
\text { students on healthy } \\
\text { food habits during } \\
\text { their acculturation. }\end{array}$ \\
\hline 3 & $\begin{array}{l}\text { Bao-Liang Zhong, } \\
\text { et.al (2020) } \\
\text { Public Health } \\
\text { Residents of Hubei } \\
\text { Province, CHINA }\end{array}$ & $\begin{array}{l}\text { Chinese residents' } \\
\text { KAP towards } \\
\text { adherence to } \\
\text { control measures } \\
\text { on COVID-19 } \\
\text { During the quick } \\
\text { ascent time of the } \\
\text { pandemic }\end{array}$ & $\begin{array}{l}\text { Self-developed } \\
\text { online questionnaire } \\
\text { was distributed } \\
\text { among local } \\
\text { residents in Hubei } \\
\text { Province. Sample } \\
\text { size is } 6910 \text { and } \\
\text { Multiple Logistic } \\
\text { regression analysis } \\
\text { was adopted to run } \\
\text { the data. }\end{array}$ & $\begin{array}{l}\text { When COVID-19 } \\
\text { information KAP } \\
\text { scores are higher, } \\
\text { probability } \\
\text { adverse } \\
\text { perspectives along } \\
\text { with possibly risky } \\
\text { practices are lower. }\end{array}$ \\
\hline 4 & $\begin{array}{l}\text { Ahmed } \\
\text { et.al (2020) } \\
\text { Education (Medical } \\
\text { students) } \\
\text { EGYPT }\end{array}$ & $\begin{array}{l}\text { the cross-sectional } \\
\text { examination was } \\
\text { carried out to } \\
\text { understand lack } \\
\text { KAP of } \\
\text { antimicrobial } \\
\text { stewardship among } \\
\text { the undergraduate } \\
\text { clinical students }\end{array}$ & $\begin{array}{l}\text { The investigation } \\
\text { adopted } \\
\text { Convenience } \\
\text { Sampling and utilized } \\
\text { Chi-Square, Mann- } \\
\text { Whitney test and } \\
\text { Kruskal-Wallis test. } \\
963 \text { Respondents } \\
\text { from } 25 \text { clinical } \\
\text { schools participated } \\
\text { in filling the } \\
\text { questionnaire. }\end{array}$ & $\begin{array}{l}\text { Instructive projects } \\
\text { about antimicrobial } \\
\text { administration and } \\
\text { the function of } \\
\text { medical services } \\
\text { experts in } \\
\text { forestalling AMR } \\
\text { ought to be } \\
\text { presented right off } \\
\text { the bat in clinical } \\
\text { educational } \\
\text { programs. }\end{array}$ \\
\hline
\end{tabular}




\begin{tabular}{|c|c|c|c|c|}
\hline 5 & $\begin{array}{l}\text { LESLEY C LUBOS } \\
\text { (2019), } \\
\text { Public good } \\
\text { Residents } \\
\text { Cagayan de Oro City, } \\
\text { MINDANAO, } \\
\text { PHILIPPINES }\end{array}$ & 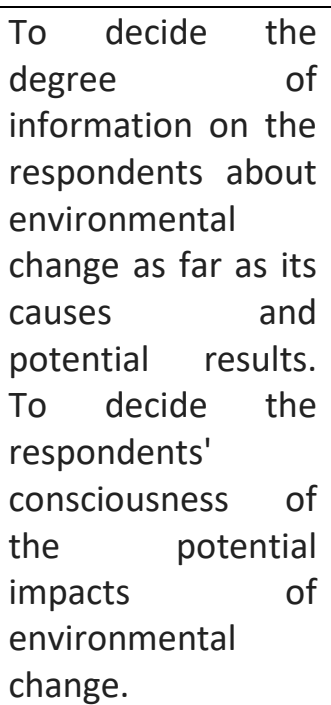 & $\begin{array}{l}\text { Adopted Descriptive } \\
\text { Quantitative } \\
\text { research design, } \\
\text { stratified purposeful } \\
\text { sampling was used } \\
\text { among } 1208 \\
\text { respondent's data } \\
\text { were collected from } \\
22 \text { villages. Statistical } \\
\text { tools like frequency } \\
\text { counts, percentage } \\
\text { and weighted mean } \\
\text { were used. }\end{array}$ & $\begin{array}{l}\text { The susceptible } \\
\text { sector ought to be } \\
\text { associated with } \\
\text { figuring } \\
\text { environmental } \\
\text { change activity } \\
\text { plans in the local } \\
\text { administration. }\end{array}$ \\
\hline 6 & $\begin{array}{l}\text { Ms.VarshaRammaiya } \\
\text { et.al (2019), } \\
\text { Banking (E-Banking) } \\
\text { INDORE, INDIA }\end{array}$ & $\begin{array}{l}\text { To highlight the } \\
\text { security problems } \\
\text { of Online Banking } \\
\text { thereby analyze the } \\
\text { trend of E-banking } \\
\text { with the help of } \\
\text { primary data. }\end{array}$ & $\begin{array}{l}\text { The study has been } \\
\text { conducted in the } \\
\text { Indore city of } \\
\text { Madhya Pradesh, } \\
\text { India. } 100 \text { customers } \\
\text { were selected by the } \\
\text { convenient sampling } \\
\text { method }\end{array}$ & $\begin{array}{l}\text { Internet banking } \\
\text { services provide a } \\
\text { large number of } \\
\text { services and } \\
\text { provide a large } \\
\text { number of benefits } \\
\text { to customers as } \\
\text { well as to business } \\
\text { for their } \\
\text { sustainability }\end{array}$ \\
\hline 7 & $\begin{array}{l}\text { Francis Oremo et.al } \\
\text { (2019), } \\
\text { Agriculture } \\
\text { (Irrigators) } \\
\text { KENYA. }\end{array}$ & $\begin{array}{l}\text { Studies show } \\
\text { different conditions } \\
\text { that impact KAP } \\
\text { according to water } \\
\text { management }\end{array}$ & $\begin{array}{lr}\text { Regression } & \text { model } \\
\text { was used to run a } \\
\text { sample size of } 279 \\
\text { farmers } \\
\text { households } & \text { or } \\
\text { TSAVO } & \text { Sub } \\
\text { catchment area } & \end{array}$ & $\begin{array}{l}\text { Subsequently, } \\
\text { better information } \\
\text { and comprehension } \\
\text { of water } \\
\text { management issues } \\
\text { show up as a pre- } \\
\text { condition for } \\
\text { harnessing benefit } \\
\text { in water } \\
\text { administration }\end{array}$ \\
\hline 8 & $\begin{array}{l}\text { Minghui Zhaoet.al } \\
\text { (2019), } \\
\text { Health Care Workers } \\
\text { CHANGCHUN, } \\
\text { CHINA }\end{array}$ & $\begin{array}{lr}\begin{array}{l}\text { focuses } \\
\text { understand }\end{array} & \text { to } \\
\text { KAP } & \text { the } \\
\text { information } & \text { and } \\
\text { request } & \text { with } \\
\text { regards } & \text { to } \\
\text { murkiness and its } \\
\begin{array}{ll}\text { consequences for } \\
\text { wellbeing }\end{array}\end{array}$ & $\begin{array}{l}\text { A purposive sample } \\
\text { containing working } \\
\text { populace, traffic } \\
\text { police, } \\
\text { undergraduates, and } \\
\text { elder populace of } \\
888 \text { inhabitants were } \\
\text { examined and Chi- } \\
\text { square was utilized } \\
\text { to run the } \\
\text { investigation }\end{array}$ & $\begin{array}{l}\text { Giving mindfulness } \\
\text { on suitable } \\
\text { practices will assist } \\
\text { with diminishing } \\
\text { the impeding } \\
\text { impacts, and urge } \\
\text { individuals to } \\
\text { effectively partake } \\
\text { in and to monitor } \\
\text { and control } \\
\text { contamination. }\end{array}$ \\
\hline 9 & $\begin{array}{l}\text { SoufianeZegraoui } \\
\text { et.al(2018) } \\
\text { Medical, } \\
\text { MOROCCO }\end{array}$ & $\begin{array}{l}\text { The purpose of this } \\
\text { examination was to } \\
\text { investigate the KAP } \\
\text { of the liberal } \\
\text { physicians on }\end{array}$ & $\begin{array}{l}\text { The questionnaire } \\
\text { affected } 120 \text { doctors } \\
\text { and used Random } \\
\text { sampling } \\
\text { SPSS tool for data }\end{array}$ & $\begin{array}{l}\text { The after-effects of } \\
\text { this investigation } \\
\text { demonstrated that } \\
\text { the mentalities of } \\
\text { wellbeing experts }\end{array}$ \\
\hline
\end{tabular}




\begin{tabular}{|c|c|c|c|c|}
\hline & & $\begin{array}{l}\text { adhering to the } \\
\text { countries policy } \\
\text { agreed under } \mathrm{MHI} \\
\text { programme }\end{array}$ & analysis. & $\begin{array}{l}\text { towards the } \\
\text { national } \\
\text { undertaking agreed } \\
\text { under the medical } \\
\text { coverage } \\
\text { programme lean on } \\
\text { the non-regard of } \\
\text { the national taxes }\end{array}$ \\
\hline 10 & $\begin{array}{l}\text { Illiyyeen Fatimaet.al } \\
\text { (2018) } \\
\text { Medical (Optometric } \\
\text { Services), } \\
\text { PAKISTAN }\end{array}$ & $\begin{array}{l}\text { The principle goal } \\
\text { of this examination } \\
\text { was to evaluate the } \\
\text { KAP with respect to } \\
\text { optometric } \\
\text { administrations } \\
\text { among general } \\
\text { experts in Lahore }\end{array}$ & $\begin{array}{l}\text { Directed among } 95 \\
\text { general professionals } \\
\text { with respect to } \\
\text { Optometric } \\
\text { administrations. } \\
\text { Study used } \\
\text { Random sampling } \\
\text { and } \\
\text { Percentage analysis }\end{array}$ & $\begin{array}{l}\text { Information } \\
\text { appraisal indicated } \\
\text { that they had } \\
\text { respectably } \\
\text { reasonable degree } \\
\text { of information with } \\
\text { respect to } \\
\text { optometric } \\
\text { administrations } \\
\text { though their } \\
\text { mentalities were } \\
\text { enough sure yet } \\
\text { they didn't use } \\
\text { their insight in their } \\
\text { General Practice. }\end{array}$ \\
\hline 11 & $\begin{array}{l}\text { M.I.C.Azami et.al } \\
\text { (2018) } \\
\text { Construction } \\
\text { MALAYSIA }\end{array}$ & $\begin{array}{l}\text { This investigation is } \\
\text { to decide the } \\
\text { hindrances for } \\
\text { temporary workers } \\
\text { in Malaysia in } \\
\text { adopting green } \\
\text { construction }\end{array}$ & $\begin{array}{l}\text { The investigation } \\
\text { utilized Cronbach's } \\
\text { alpha and random } \\
\text { sampling was used } \\
\text { to select a sample } \\
\text { size of } 40 \text {. }\end{array}$ & $\begin{array}{l}\text { The outcomes show } \\
\text { that, KAP of the } \\
\text { contractual workers } \\
\text { in Malaysia on } \\
\text { green development } \\
\text { is acceptable, yet } \\
\text { their degree of } \\
\text { disposition are too } \\
\text { low and horrible on } \\
\text { the grounds that } \\
\text { green development } \\
\text { will bring about } \\
\text { additional time and } \\
\text { cost. }\end{array}$ \\
\hline 12 & $\begin{array}{l}\text { Xinmiao Luo et.al } \\
\text { (2018) } \\
\text { Medical } \\
\text { CHINA }\end{array}$ & $\begin{array}{l}\text { This examination } \\
\text { plans to look at the } \\
\text { food safety (KAP) } \\
\text { among the } \\
\text { undergraduates } \\
\text { from nursing, } \\
\text { education and } \\
\text { medical colleges }\end{array}$ & $\begin{array}{l}\text { The study was } \\
\text { directed among } 3454 \\
\text { clinical } \\
\text { undergraduates and } \\
\text { nursing students. } \\
\text { The study used } \\
\text { cluster sampling } \\
\text { method and } \\
\text { Tool used was } \\
\text { ANOVA. }\end{array}$ & $\begin{array}{l}\text { In comparison to } \\
\text { the medical } \\
\text { students, the } \\
\text { nursing students } \\
\text { scored lower on } \\
\text { Knowledge and } \\
\text { practice, yet higher } \\
\text { on attitude. } \\
\text { Education on food } \\
\text { safety ought to be } \\
\text { performed among } \\
\text { nursing, training } \\
\text { and medical } \\
\text { students. }\end{array}$ \\
\hline
\end{tabular}




\begin{tabular}{|c|c|c|c|c|}
\hline 13 & $\begin{array}{l}\text { James Muleme et.al } \\
\text { (2017) } \\
\text { Medical (Public } \\
\text { Health) } \\
\text { UGANDA }\end{array}$ & $\begin{array}{l}\text { These } \\
\text { examinations are } \\
\text { typically pointed } \\
\text { toward identifying } \\
\text { benchmarks that } \\
\text { can advise and } \\
\text { improve the } \\
\text { growth and } \\
\text { incorporation of } \\
\text { PHIs. }\end{array}$ & $\begin{array}{l}\text { Quantitative } \\
\text { information was } \\
\text { gathered utilizing a } \\
\text { questionnaire from } \\
167 \text { families. } \\
\text { The study used } \\
\text { Random sampling } \\
\text { and } \\
\text { Regression analysis } \\
\text { tool. }\end{array}$ & $\begin{array}{lr}\text { pesticide security } \\
\text { mindfulness } \\
\text { mission would just } \\
\text { be powerful as } \\
\text { leading } & \text { an } \\
\text { adjustment } \\
\text { conduct across } \\
\text { family units with } \\
\text { restricted } \\
\text { information }\end{array}$ \\
\hline 14 & $\begin{array}{l}\text { RabiaTabassum et.al } \\
\text { (2017) } \\
\text { Public Good } \\
\text { (Social Security) } \\
\text { KP \& PUNJAB }\end{array}$ & $\begin{array}{l}\text { The study to } \\
\text { measure } \\
\text { knowledge attitude } \\
\text { and practices of } \\
\text { people, particularly } \\
\text { poor and } \\
\text { vulnerable people } \\
\text { on social protection } \\
\text { schemes }\end{array}$ & $\begin{array}{l}\text { Conducted in } 1200 \\
\text { households( } 300 \text { per } \\
\text { each districts) } \\
\text { The study used } \\
\text { Stratification } \\
\text { sampling and } \\
\begin{array}{l}\text { Percentage analysis } \\
\text { as tools. }\end{array}\end{array}$ & $\begin{array}{l}\text { The results of the } \\
\text { survey demonstrate } \\
\text { significant } \\
\text { knowledge gap } \\
\text { concerning social } \\
\text { assistance } \\
\text { programmes in } \\
\text { selected districts. } \\
\text { This could be } \\
\text { mainly due to } \\
\text { inadequate } \\
\text { information } \\
\text { dissemination in } \\
\text { rural areas. }\end{array}$ \\
\hline 15 & $\begin{array}{l}\text { Morgera, Elisa } \\
\text { (Principal } \\
\text { Investigator) } \\
\text { Public Good (Food } \\
\text { Safety) } \\
\text { WBGS }\end{array}$ & $\begin{array}{l}\text { The study to profile } \\
\text { and analyze KAP on } \\
\text { food safety } \\
\text { amongst } \\
\text { households in } \\
\text { order to obtain a } \\
\text { better } \\
\text { understanding of } \\
\text { current levels of } \\
\text { knowledge and } \\
\text { practices } \\
\text { \&educational } \\
\text { awareness }\end{array}$ & $\begin{array}{l}\text { Survey covered } 1 \\
135 \text { households } \\
\text { distributed across } \\
\text { the WBGS. } \\
\text { The study used } \\
\text { Random sampling } \\
\text { and Percentage } \\
\text { analysis }\end{array}$ & $\begin{array}{l}\text { The finding of this } \\
\text { study identifies } \\
\text { major gaps in food } \\
\text { safety KAPs. Survey } \\
\text { findings define } \\
\text { strategies for the } \\
\text { development of an } \\
\text { effective awareness } \\
\text { campaign to } \\
\text { promote food- } \\
\text { safety best } \\
\text { practices across the } \\
\text { food handling life } \\
\text { cycle. }\end{array}$ \\
\hline 16 & $\begin{array}{l}\text { M.A.K. } \\
\text { A.K.B. ROHIN(2016) } \\
\text { Medical (Hospital) } \\
\text { Terengganu } \\
\text { MALAYSIA }\end{array}$ & $\begin{array}{l}\text { This investigation } \\
\text { was led to consider } \\
\text { the degree of KAP } \\
\text { on good } \\
\text { manufacturing } \\
\text { practices (GMP) } \\
\text { among food } \\
\text { overseers in } \\
\text { Terengganu clinics }\end{array}$ & $\begin{array}{l}\text { convenience } \\
\text { sampling was done } \\
\text { with } 4 \text { hospitals and } \\
\text { SPSS is used. }\end{array}$ & $\begin{array}{l}\text { As the end, } \\
\text { powerful and } \\
\text { mandatory food } \\
\text { safety training on a } \\
\text { normal and } \\
\text { progressing } \\
\text { premise ought to } \\
\text { be featured and led } \\
\text { for all food service } \\
\text { workers so as to } \\
\text { limit the } \\
\text { commonness of } \\
\text { food borne perils. }\end{array}$ \\
\hline
\end{tabular}




\begin{tabular}{|c|c|c|c|c|}
\hline 17 & $\begin{array}{l}\text { Phillip Nessie Bryan } \\
\text { Da Silva (2015) } \\
\text { Education, } \\
\text { Guyana }\end{array}$ & $\begin{array}{l}\text { Teachers } \\
\text { awareness towards } \\
\text { management, } \\
\text { conservation of } \\
\text { mangroves and } \\
\text { Inclusion of it in the } \\
\text { subject what they } \\
\text { teach. }\end{array}$ & $\begin{array}{l}\text { Questionnaire was } \\
\text { administered among } \\
\text { the } 120 \text { Teachers of } \\
\text { two areas from } \\
\text { Guyana. The } \\
\text { collected data were } \\
\text { processed using SPSS } \\
\text { and tests like Chi- } \\
\text { square, t-tests, and } \\
\text { Kendall's Coefficient. }\end{array}$ & $\begin{array}{l}\text { The findings of the } \\
\text { study reveal that } \\
\text { teachers KAP level } \\
\text { was good and there } \\
\text { exists a positive } \\
\text { approach to } \\
\text { manage and } \\
\text { conserve the } \\
\text { mangroves and also } \\
\text { to include it in the } \\
\text { teaching. }\end{array}$ \\
\hline 18 & $\begin{array}{l}\text { HumnaMehtab et.al } \\
\text { (2015) } \\
\text { Banking, } \\
\text { PAKISTAN }\end{array}$ & $\begin{array}{l}\text { To identify the KAP } \\
\text { of Islamic and } \\
\text { traditional bank in } \\
\text { Peshawar. }\end{array}$ & $\begin{array}{l}\text { A subjective sample } \\
\text { size } 400 \text { customers } \\
\text { with banks accounts } \\
\text { was selected. } 200 \text { in } \\
\text { Islamic banks and } \\
200 \text { in conventional } \\
\text { banks. } \\
\text { The study used } \\
\text { Random sampling } \\
\text { and Chi-square test. }\end{array}$ & $\begin{array}{l}\text { The examination of } \\
\text { KAP review affirms } \\
\text { the relationship } \\
\text { among the KAP of } \\
\text { Islamic banking and } \\
\text { furthermore gives } \\
\text { that Islamic banks } \\
\text { need to attend on } \\
\text { making more } \\
\text { noteworthy } \\
\text { familiarity with } \\
\text { Islamic banking } \\
\text { products and } \\
\text { administrations } \\
\text { among clients }\end{array}$ \\
\hline 19 & $\begin{array}{l}\text { Kolbe KD (2015) } \\
\text { Education } \\
\text { ENGLAND }\end{array}$ & $\begin{array}{l}\text { To discover what } \\
\text { similarities and } \\
\text { contrasts in sees } \\
\text { with respect to } \\
\text { waste management } \\
\text { exist between } \\
\text { grammar school } \\
\text { pupils and } \\
\text { comprehensive } \\
\text { school students in } \\
\text { England. }\end{array}$ & $\begin{array}{l}\text { The survey was done } \\
\text { in two schools in the } \\
\text { same city which has } \\
\text { a population of } \\
\text { around } 100,000 \text {. The } \\
\text { study used Random } \\
\text { sampling and SPSS } \\
\text { tool. }\end{array}$ & $\begin{array}{l}\text { Both schools } \\
\text { required to feature } \\
\text { the significance of } \\
\text { waste decrease } \\
\text { along with waste } \\
\text { re-use contrasted } \\
\text { with reusing. }\end{array}$ \\
\hline 20 & $\begin{array}{l}\text { Jamilah Ahmad } \\
\text { et.al(2015) } \\
\text { Education } \\
\text { MALAYSIA }\end{array}$ & $\begin{array}{l}\text { This examination } \\
\text { explored the } \\
\text { connection } \\
\text { between students' } \\
\text { KAP of the climate } \\
\text { and } \\
\text { also, viable } \\
\text { communication of } \\
\text { environmental } \\
\text { messages }\end{array}$ & $\begin{array}{l}895 \text { Students from } \\
\text { sixteen higher } \\
\text { education } \\
\text { organizations in } \\
\text { Malaysia } \\
\text { participated. } \\
\text { The study used } \\
\text { Random sampling } \\
\text { and Correlation as } \\
\text { tool. }\end{array}$ & $\begin{array}{l}\text { Pupils in general, } \\
\text { have a satisfactory } \\
\text { level of } \\
\text { environmental } \\
\text { knowledge. It also } \\
\text { suggested that the } \\
\text { internet is } \\
\text { considered to be } \\
\text { the best choice of } \\
\text { media to } \\
\text { disseminate } \\
\text { environmental } \\
\text { information }\end{array}$ \\
\hline
\end{tabular}




\section{Conclusion}

The aim of the study is to investigate and analyse how effective the earlier KAP studies are towards the sustainability. Based on the results, it can be concluded that the world is currently facing an array of planetary emergencies. Hence the need of sustainability is essential in every field. For this KAP studies are necessary. Most of the KAP studies are addressed in health, medicine and education sectors. More dietary knowledge during acculturation is required to avoid unhealthy effects (Xiyao Liu et.al, 2020).There are studies addressed on educational sector, Mohammad Zohar Ahmadet.al(2017), finally, the research team would like to recommend further research to improve and enhance the questionnaire's to measure teachers KAP in ESD especially for items that have scientific terminologies to include descriptions that is friendly to all fields of education and not to scientist alone and Kolbe KD (2015), The examination demonstrated that there are contrasts between sentence structure school understudies and complete school understudy's information, mentalities and conduct with respect to squander the executives. There is a need in the two schools to feature the significance of waste decrease and waste re-use contrasted with reusing. In clinical field Ahmed Assar et.al (2020), Educational projects about antimicrobial stewardship and the part of medical services experts in forestalling AMR ought to be presented right off the bat in clinical educational programs. KAP concentrates likewise manages Islamic banking (Muhammad Uzair Ali et.al, 2020) and E-Banking (VarshaRammaiya et.al 2019).

\begin{tabular}{|l|l|l|}
\hline \multicolumn{1}{|c|}{ Sectors Most Addressed } & Sectors Moderately Addressed & Sectors Least Addressed \\
\hline Public Health (5) & Banking\& Insurance (3) & Agriculture (1) \\
\hline Education (5) & & Construction (1) \\
\hline Medicine (5) & & \\
\hline
\end{tabular}

The purpose of this paper was to find out the important sectors where the earlier KAP studies are addressed from literature review. So, about 20 literatures were investigated deeply and the most extracted sectors were gauged. Public Health, Education and Medicine where the most addressed sectors used in the literatures which give a positive relationship with sustainability. The KAP studies in Banking and Insurance industries are moderate. Agriculture and construction were the least addressed. The aim of this paper is to find out the scope of the KAP study on sustainability in the research area. Hence this paper shows the significance of KAP in various fields in order to obtain sustainability.

\section{Suggestions}

Based on the above discussion this paper conveys further that the researchers who are interested to do carry out study on KAP towards sustainability can address on sectors which are moderately addressed and least addressed in particular. As in this paper the sectors which are discussed most are Public health, Education, and Medicine. There are many sectors like Small Finance Bank, services, industrials etc still untouched which affect the sustainability issues. So, it is relevant to do research on KAP study towards sustainability on such sectors. Hence there is a wider scope on KAP study in research area.

\section{References}

1. Ahmed Assar, Mohamed Ibrahim Abdelraoof, Mohamed Abdel-Maboud, Kerollos Shaker, AmrMenshawy, Asia Hamdy Swelam, . . Mohamed Abdel-Daim. (2020, April). Knowledge, attitudes, and practices of Egypt's future physicians towards antimicrobial resistance (KAP-AMR study): a multicenter cross-sectional study. Environmental Science and Pollution Research, 27(17), 1-7. 
2. Bao-Liang Zhong, Wei Luo, Hai-Mei Li, Qian-Qian Zhang, Xiao-Ge Liu, Wen-Tian Li, \& Yi Li. (2020). Knowledge, attitudes, and practices towards COVID-19 among Chinese residents during the rapid rise period of the COVID-19 outbreak: a quick online cross-sectional survey. International Journal of Biological Sciences, 16(10), 1745 - 1752.

3. Francis Oremo, Richard Mulwa, \& Nicholas Oguge. (2019, July). Knowledge, Attitude and Practice in Water Resources Management among Smallholder Irrigators in the Tsavo Sub-Catchment, Kenya, 8(3), 130.

4. Humna Mehtab, Zafar Zaheer, \& Shahid Ali. (2015, January). Knowledge, Attitudes and Practices (KAP) Survey: A Case Study on Islamic Banking at Peshawar, Pakistan. FWU Journal of Social Sciences, 9(2), 1-13.

5. Illiyyeen Fatima, \& Imran Ahmad. (2018). Knowledge, Attitude, Practice (KAP) study regarding optometric services among general practitioners in Lahore. Ophthalmology Pakistan, 8(1), 14-17.

6. James Muleme, Clovice Kankya, John C. Ssempebwa, Stella Mazer, \& Adrian Muwonge. (2017). A framework for integrating qualitatyive and quantitative data in KAP studies: case study of pesticide usage in Eastern uganda. Frontiers in public health, 5, [318].

7. Jamilah Ahmad, Shuhaida Md. Noor, \& Nurzali Ismail. (2015, June). Investigating Students' Environmental Knowledge, Attitude, Practice and Communication. Asian Social Science, 11(16), 284-293.

8. Karin Dorina Kolbe. (2015). Knowledge, Attitudes and Behaviour regarding Waste Management in a Grammar and a Comprehensive School in England-Results from a School Questionnaire. Journal of Teacher Education for Sustainability, 17(1), 58-71

9. Lesley Lubos, \& Lalevie Casas Lubos. (2018). Knowledge, Attitudes, Practices, and Action on Climate Change and Environmental Awareness of the Twenty-two Villages along the River Banks in Cagayan de Oro City, Philippines. Liceo Journal of Higher Education Research, 9(1), 65-83.

10.M.I.C.Azami , A. H. Alias, S. Hassim, N. A. Haron,, N. S. N. Ezani, \& M. A. Jaafar. (2018). On the usage of KAP in analyzing the barriers in practicing green construction in Malaysia. American Institute of Physics, 126(1), 38-44.

11.Minghui Zhao, Meiling Zhang, Jie Ying, Shouqi Wang, Ying Shi, Huanhuan Li, Jiao Sun. (2019). Knowledge, attitudes, practices and information demand in relation to haze in China: a crosssectional study. BMC Public Health, 19(1396), 1-11.

12.Ms.Varsha Rammaiya, \& Dr. Gyan Prakash. (2019, Jan-June). KAP STUDY OF E-BANKING IN INDORE. Amity Journal of Management, 7(1), 13-21.

13. Muhammad Uzair Ali, Gong zhimin, Muhammad Rizwanullah, Xiong Wu, \& Itbar khan. (2020). A Survey of "Knowledge, Attitudes \& Practices" of Islamic Banking Clients: An Evidence from FATA and PATA, Pakistan. Risk and Financial Management, 1(1), 40-50.

14.FAOU (2017). Food safety knowledge, attitudes and practices (KAP) among food consumers in the West Bank and Gaza Strip. Survey report, 1-74

15.Norhaslinda R, Norhayati A.H, \& Mohd Adzim Khalili R. (2016). Knowledge, Attitudes and Practices (Kap) On Good Manufacturing Practices (Gmp) Among Food Handlers In Terengganu Hospitals.International Journal of Pharmacy and Pharmaceutical Sciences, 8(11), 53-59.

16.Phillip Nessie Bryan Da Silva. (2015, August). Conservation of Mangroves in Guyana: A Study of Teachers' Perceptions, Knowledge, Attitudes and Practices. Research Journal of Chemical and Environmental Sciences, 3(4), 1-8.

17.Rabia Tabassum, Dr.Shehryar Khan Toru, \& Mohsin Ali Kazmi. (2017). Knowledge Attitude and Practices survey on social protection schemes in selective districts. Survey report, 1-70

18.Salas - Zapta, W., Rios-Osorio, L., \& Cardona-Arias, J. (2018). Knowledge, Attitudes and Practices of Sustainability: Systematic review 1990-2016. Journal of Teacher Education for Sustainability, 20(1), 46-63.

19.Soufiane Zegraoui, Amine Cheikh, Mustapha Bouatia, Mohamed Rida Ajaja, Saida Naji, \& Amine El Hassani. (2018). Knowledge, attitudes and practices of the liberal doctors in relation to the national convention signed in the framework of Mandatory Health Insurance in Morocco: a crosssectional study. Pan African Medical Journal, 8(4), 1-7. 
20.Xinmiao Luo, Xianglong X, Hua Chen, Ruixue Bai, Yan Zhang, Xiaorong Hou, . . Yong Zhao. (2018). Food safety related knowledge, attitudes, and practices (KAP) among thestudents from nursing, education and medical college in Chongqing, China. Food Control, 9(2), 181-188.

21.Xiyao Liu, Haoyue Chen, Qianling Zhou, Huifeng Zhang, Phensiri Asawasirisap, \& John Kearney. (2020). Knowledge, Attitude and Practices (KAP) towards Diet and Health among International Students in Dublin: A Cross-Sectional Study. International Journal of Environmental research and Public Health, 17(9), 1-13. 